\title{
ANALYSIS OF LOCAL RAW MATERIALS AND THEIR USE INSTEAD OF TRADITIONAL ONES IN VARIOUS FIELDS Movlayev I.G. ${ }^{1}$, Ibrahimova S.M. ${ }^{2}$, Mamedova G.M. ${ }^{3}$ Email: Movlayev1140@scientifictext.ru
}

\author{
${ }^{I}$ Movlayev Ibrahim Gumbat oglu - Candidate of Technical Sciences, Associate Professor; \\ ${ }^{2}$ Ibrahimova Sinduz Mamed qizi-Senior Teacher, \\ DEPARTMENT OF TECHNOLOGY OF ORGANIC AND HIGHMOLECULAR COMPOUNDS; \\ ${ }^{3}$ Mammadova Gulnura Mustafa qizi - Candidate of Technical Sciences, Associate Professor, \\ DEPARTMENT OF CHEMISTRY AND INORQANIC SUBSTANCE TECHNOLOGY, \\ FACULTY OF CHEMICAL TECHNOLOGY, \\ AZERBAIJAN STATE UNIVERSITY OF OIL AND TECHNOLOGY, \\ BAKU, REPUBLIC OF AZERBAIJAN
}

\begin{abstract}
: brief review of the carried out researches concerning the use of untraditional raw material in various fields has been presented in the article.

As a result of the analysis of nontraditional raw materials it has been determined that a large amount of industry wastes containing significant compounds is formed in our country. It has been shown that the quantity and viscosity of significant compounds in their content make possible to substitute expensive, heavily found raw material and use them in various fields.

Carried out researches and obtained results have shown the possibility of effective use of industrial wastes containing significant compounds in various fields instead of traditional raw materials.

Widening of raw material variety and preserving natural raw material resources are of great importance from economical and ecological points of view.

Keywords: industrial wastes, unconventional raw materials, rubber compounds, fillers, vulcanization activator, dolomite, lime, fertilizer, aluminum fluoride, red slime - waste processing of alunite, zeolite.

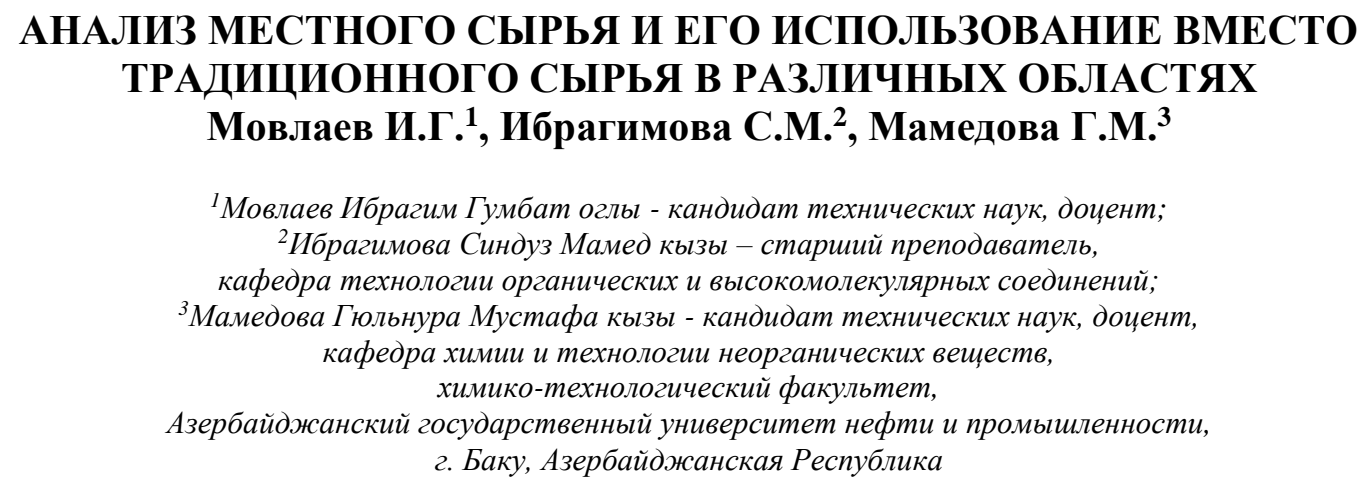

Аннотация: в статье представлен краткий обзор выполненных нами исследований, посвященных использованию нетрадиционного сырья в различных областях.

Анализ местных источников сырья показал, что в нашей стране образуется большое количество производственных отходов, содержащих ценные соединения. Установлено, что количество этих отходов и концентрация содержашихся в них иенных соединений, позволяют использовать их взамен дорогого и дефицитного традиџионного сырья в различных областях.

Проведенные исследования и полученные результаты показали возможность эффективного использования ряда производственных отходов в различных областях взамен традиционного сырья, что имеет большое значение, как с точки зрения сохранения запасов природного сырья, так и с экономической и экологической точек зрения.

Ключевые слова: производственные отходы, нетрадиционное сырье, резиновые смеси, наполнители, активатор вулканизации, доломит, известковое удобрение, фторид алюминия, красный шлам - отход переработки алунита, цеолит.

UDC 678.632

Study of polymers is one of the urgent problems from ecological and economical points of view. Global pollution of the environment and sharp decrease of natural resources will cause human undoing and it shows necessity of solution of problem of environment protection and preserving of natural raw materials. At present one of the most important conditions for widening and intensifying industrial production is the creating of reliable raw materials base. That's why attraction of non - traditional raw materials to the industry is of great interest. 
Study of local raw materials resources shows that a big quantity industry and welfare wastes containing valuable compounds are formed and it results loss of significant raw materials. From other side, these wastes influence negatively human organism and create ecological problems. Utilization of wastes is of great significance in solution of the problem.

That's why use of industry and welfare wastes, instead of traditional raw materials make possible to extend variety of raw materials, preserve natural resources, solve economic and ecological problems.

Nowadays it is impossible to imagine a number of fluids without polymers.

Current scientific - researches in the field of obtaining of polymer materials are directed not to new polymers synthesis, but - to the modification of existing polymers or to creation of new profile composition materials. In the modern rubber industry variety of items meeting various requirements are produced. It creates need in preparing receipts of a big quantity of rubber mixtures distinguishing for technological and physico-mechanical properties [1-12].

In connection with dynamic development in the industry the increase in demand to tyres and rubber items is observed. One of the urgent problems is to increase variety of ingredients included into the content of tyres and rubber-technical items and decrease the cost of rubber mixtures. One of the most effective methods is to form complex exploitation properties of composition material to fill them with fillers. Adding of fillers improves technological and physico-mechanical properties of composition materials, decreases its cost and increases economic efficiency of their use. At present technical carbon is used as filler in rubber mixtures [13-14]. When adding technical carbon to rubber mixture, viscosity of mixtures increases, plasticity decreases at the expense of hydrodynamic efficiency and also as a result of interaction of elastomer with technical carbon. Strain and strength of vulcanizers during the elongation increase significantly, relative elongation and elasticity decrease, strength in tension and resistance against the friction have maximum value during optimal filling.

Together with positive properties, elastomer with technical carbon has also disadvantages. Because technical carbon is not produced in our Republic, it costs expensive, influences negatively human organism and pollutes environment. That is why substitution of technical carbon - the traditional filler in rubber mixtures is an urgent problem.

Considering it local raw material resources have been studied and Azerbaijan became famous for availability of hydrocarbon resources and mineral reserves. But during the development of mineral raw materials fields approximately $60-70 \%$ of it is a product, the rest is a waste (small, not the part of commodity) or dust and it causes loss of significant raw material and environment pollution. So, use of the shown wastes is of great significance both from economic and ecological points of view.

Carried out researches showed that quantity and properties of these wastes make possible to use them in various fields including as a filler in rubber mixtures.

Considering above mentioned technical carbon used as traditional filler in protector, frame, autotyre and rubber mixtures receipt was substituted by the waste formed during the development of dolomite fields and properties of vulcanizers of the obtained rubbers have been studied [15-16].

Dolomite powder obtained as a result of dolomite wastes grinding containing

$\mathrm{CaO}-29,6 ; \mathrm{MgO}-19,5 ; \mathrm{F}_{2} \mathrm{O}_{3}-0,5 ; \mathrm{Al}_{2} \mathrm{O}_{3}-0,14 ; \mathrm{CoO}-0,15 ; \mathrm{MnO}-0,10 ; \mathrm{NiO}-0,11 ; \mathrm{ZnO}-0,13 ; \mathrm{SiO}_{2}$ $-2,14 ; \mathrm{CO}_{2}-46,72 \%$ has been used for the researches.

It has been determined that substitution of $24-30 \%$ technical carbon in protector, frame and auto tyre rubber mixtures and in side rubber mixture with $60-70 \%$ waste obtained in dolomite fields development makes possible to improve economic and ecological indices of rubber production keeping physico-mechanical and exploitation properties of the obtained rubber vulcanizers in tyre industry for making rubber valves of the auto inner tubes. White soot (BC-120) is used to increase relation strength of rubber with valves [13-14]. Considering that traditional mineral filler - white soot is expensive, heavily found and influences human organism as heavy toxic substance, its substitution with easily found, cheap, non-toxic ingredients is an urgent problem.

In connection with it white soot was substituted with multi-tonnage waste of fluoride production- high disperse silicium gel and properties of the vulcanizers of the obtained rubbers have been studied [17]. For researches low content silicium gel has been used, mass percent in dry substance $\mathrm{SiO}_{2}$ should not be less than $70 \%$; aluminum is not more than $9 \%$; humidity is not less than $3 \% ; \mathrm{H}_{2} \mathrm{SiF}_{6}$ is not more $0,8 \%(+\mathrm{S}-6-08-465$ $-81)$

As a result of carried out researches substitution possibility of $43-57 \%$ white soot by silicium gel has been shown. Keeping physico-mechanical and exploitation properties of vulcanizers of rubber mixtures used for auto inner tube valves it allows to solve economical and ecological problems of their production.

Vulcanizers activators are added into rubber mixtures to increase physico-mechanical properties of vulcanizers. Zink oxide is used as vulcanizers activator [13-14].

Together with positive properties, zink oxide also also has disadvantages. It is inclined to aglomelioration, it is heavily dissolved and dispersed in the rubber. That is why substitution of traditional vulcanizer activator of rubber mixtures with cheap and easily found raw material is an urgent problem. 
Considering it, local raw material sources have been analyzed and it has been determined that during the treatment of natural mineral raw material the waste material oxides containing waste is formed. Quantity of this waste and viscosity of metal oxides in its content make possible to use it in rubber mixtures as vulcanizer activators instead of sink oxide.

Considering the above mentioned, traditional vulcanizer activator - zink oxide in the receipt of rubber mixtures for protector, frame and auto inner tubes have been substituted with the waste formed during the processing of natural mineral raw material and properties of vulcanizer have been studied [18]. For the researches low content waste formed during the processing of natural mineral raw material with mass $\%: \mathrm{SiO}_{2}-$ 81,36; $\mathrm{Al}_{2} \mathrm{O}_{3}-7,46 ; \mathrm{ZnO}-7,42 ; \mathrm{MgO}-1,86 ; \mathrm{H}_{2} \mathrm{O}-0,9$ has been used. It has been determined that substitution of $30-50 \%$ zink oxide preserves physico-mechanical and explotation properties of obtained rubber vulcanizers according to the standart and makes possible to expand variety of raw material for protector frame and auto inner tube rubber production and improve economic indices.

As a result of carried out researches obtained mixtures have been offered to be applied in the production of tyres and rubber technical items.

The role of mineral fertilizers in the achievement of high productivity of agricultural plants is great. Availability of nitrogen, phosphor, potassium, calcium, magnesium, ferrum and other elements is necessary for normal life of plants [9].

Increase of productivity of agricultural plants and their quality depend on the right use of mineral fertilizers. It is necessary to know the time and quantity of fertilizer delivery, because their surplus quantity accumulates in the organisms of plants and product from such plants is useless.

It is known that lime fertilizers are used to eliminate surplus acidity of the soil. Liming increases efficiency of mineral and organic fertilizers significantly. Thus, after liming of acid soils, decomposition of organic fertilizers accelerates and as a result positive influence of the lime on soil quality increases.

During the delivery of physiological acid ammonium and potassium fertilizers having soil acidizing ability, liming especially plays positive role for soils with high acidity.

Benefit from the liming depends on the soil acidity degree, characteristics of the plant, rate and type of the fertilizer.

More is the soil acidity, more is lime rate and efficiency of liming is big too. But at present increase of lime fertilizers rates mostly causes increase of dose limit and burning of plants. It is known that magnesium is one of the most necessary nourishment elements for plants and it plays important role in physiological and biochemical processes in the plant organism. In the magnesium shortage, both quantity and quality of the product increase when it is delivered [20]. Magnesium is included into the content of various minerals, dolomite is the first of them.

In connection with above mentioned possibility of use of the waste formed during the development of calcium and magnesium carbonates containing dolomite field as a fertilizer has been achieved [21]. For researches, $\mathrm{CaO}-29,6 ; \mathrm{MgO}-19,5 ; \mathrm{Fe}_{2} \mathrm{O}_{3}-0,5 ; \mathrm{Al}_{2} \mathrm{O}_{3}-0,14 ; \mathrm{CoO}-0,15 ; \mathrm{CuO}-0,10 ; \mathrm{MnO}-0,10 ; \mathrm{NiO}-$ 0,$11 ; \mathrm{ZnO}-0,13 ; \mathrm{SiO}_{2}-2,14 ; \mathrm{CO}_{2}-46,72$ containing dolomite powder obtained during the grinding of dolomite wastes has been used.

As a result of carried out researches it has been determined that dolomite powder is seen itself in the sandy and super-sandy soils which have poor magnesium. In this case physico-chemical and biological properties of the soil improve and it becomes rich with calcium and magnesium which is in the content of chlorophyll and takes part in the photosynthesis, condition of plants improves, quality and storage ability of the product increases, efficiency of the use of mineral and organic fertilizers becomes high, connection nuclides influencing ecological purity of the product.

It has also been revealed that dolomite powder is effective means in the control with pets. Fine grinded dolomite is intoxic for alives, but it decomposes hitin covers.

Carried out researches have showed that dolomite powder obtained from the waste formed during the development of dolomite fields can be used as effective lime fertilizers for the plants sensible to the soil acidity.

Inorganic chemistry industry is of great significance for country economy. It is known that aluminum fluoride is very important and valuable component in aluminum production. Aluminum hydroxide and silicium hexafluoride acid is used as raw material in aluminum fluoride production [22]. But nowadays aluminum hydroxide is heavily found and expensive raw material. That is why its substitution with cheap, easily found, aluminum containing raw material is one of the urgent problems.

Researches carried out with this purpose have shown that in Gandja clay-soil enterprise alunite and bauxite slimes containing aluminum oxide is formed. Currently, there are $12 \mathrm{mln} 730000 \mathrm{t}$ alunite slime in the alunite slime basin, but in bauxite slime basin there are 8843000 ton bauxite slime. It also seriously influences on environment pollution in that zone. If to consider they contain valuable metal oxides, use of these wastes is an urgent problem both from economic of and ecological points of view. From the other side it is known that as a result of absorption of fluoride gases emitted in the process of simple superphosphate production, a large amount 
of $12-14 \%$ silicium-hexafluoride acid is obtained as a waste $\left(\mathrm{H}_{2} \mathrm{SiF}_{6}\right.$ is not less than $12-14 \%$; $\mathrm{P}_{2} \mathrm{O}_{5}$ is not more than $0,03 \%$ ) TU-608-43579 [19].

If to consider all these, silicium hexafluoride acid - the waste of red slime and simple superphosphate production is offered to be used as raw material in the aluminum fluoride production technology.

With this purpose, by using red slime - the waste of Ganja clay-sand enterprise and silicium hexafluoride acid - the waste of simple superphosphate production, new manufacturing technology of aluminum fluoride has been worked out. To preserve the quality of aluminum fluoride, aluminum hydroxide is substituted by red slime [23].

For researches alunite slam with $\mathrm{SiO}_{2}-72.86-84, \mathrm{Al}_{2} \mathrm{O}_{3}-10-13 ; \mathrm{Fe}_{2} \mathrm{O}_{3}-3,83 ; \mathrm{FeO} 0,54 ; \mathrm{CaO}-0,75 ; \mathrm{TiO}_{2}-$ 0,$39 ; \mathrm{MgO}-0,001 ; \mathrm{Na}_{2} \mathrm{O}-2,55 ; \mathrm{K}_{2} \mathrm{O}-0,31-1-62 ; \mathrm{P}_{2} \mathrm{O}_{5}-0,18 ; \mathrm{SO}_{3}-3,78, \mathrm{H}_{2} \mathrm{O} 2,3$ content is used. Alunite slime is the red color dust.

Due to the new technology, mixture of aluminum content raw material - aluminum hydroxide and red slime are mixed with one part of silicium hexafluorhydric acid. It is heated to the necessary temperature then the main part of the acid is added. This technological method is allowed to reduce fluoride loss; because adding aluminum content raw material into in advance heated silicium hexafluorhydric acid some part of the acid, begins to decompose as a result of the high temperature and a large amount of the fluoride release through the reactor poisons the environment.

Influence of aluminum hydroxide and red slime on aluminum fluoride output and properties, silicium hexafluorhydric acid quantity, consequence of the components have been studied [24-25].

It has been determined that when replacing 35\% aluminum hydroxide by red slime, mixtures inside of it influence as a catalyst and the process of aluminum fluoride obtaining accelerates, degree of raw material use increases, fluoride loss decreases and product output grows.

Carried out researches showed possibility of obtaining of aluminum fluoride meeting standard requirements by using new production technology- that is replacing $35 \%$ aluminum hydroxide with red slime.

It is known that transport enterprises pollute atmosphere, soil, water environment not only with burning products, but also, old parts, aggregates, rubber items, and waste waters and as a result, disturbance of ecological balance takes place. Carried out any arrangement to avoid these influences can be appraised, but right now it is impossible to speak about satisfactory results. As it is seen from above mentioned, the problem considered to be solved one of the urgent problems of the day.

A large amount of waste waters rich with macro- and microelements are formed in the auto industry and it causes significant raw material loss. Researches have been carried out to render such waste waters harmless. But complete rendering of waste waters of auto industry and their recovery have not been realized.

Considering all these, using zeolite as absorbent, the wastes formed during the development of dolomite fields, their mixture at 1:1 ratio and offered installation, the process of rendering harmless of auto industry waste waters have been studied. The researches proved the possibility of cleaning and recovery of the auto industry waste waters completely [26].

Used absorbents - zeolite, dolomite and their mixture have been offered to be used as various construction materials and recovered waste water containing macro and microelements have been offered to be used in production of mineral fertilizers enriched with nourishment elements.

\section{References / Сиисок литературы}

1. Bilalov Y.M., Ibrahimov A.D., Ibrahimova S.M., Movlayev I.G. // "Rubber and cauchuk”. Moscow, 1998, № 3. P. 9.

2. Bilalov Y.M., Ibrahimov A.D., Ibrahimova S.M., Shvarts A.Y. // "Vulcanized rubber mixture” RF Patent № 2129575, 27.04.1999.

3. Bilalov Y.M., Ibrahimova A.S., Ibrahimova S.M., Shvarts A.Y. // "Vulcanized rubber mixture". Az.R patent P 9900014, 11.09.1999.

4. Movlayev I.G., Kerimova T.Z., Gasanova F.N. "Ozon resistant rubbers based on cauchuk mixtures/ $8^{\text {th }}$ scientific- practical conference. Rubber industry, Raw materials, technology. MSRI, 2001. P. 256-257.

5. Bilalov Y.M. "Formation of polymer composition materials with special properties // News of higher technical educational institutions of Azerbaijan, 2001. № 3-4. P. 36-42.

6. Ibrahimov A.D., Bilalov Y.M., Ibrahimova S.M., Safarov M.A. // "Modified rubbers with increased adheous properties of the basis CKU-3. Theses of reports. Raw materials technology, M.SRI, 2002. P. 173.

7. Movlayev I.G., Mamedov A.S., Ibrahimova S.M. // "Influence of various plastificators on properties of vulcanizers SREPT/PVC. Theses of reports $9^{\text {th }}$ scientific-practical conference, Raw materials, technology M.SRI, 2002. P. 258-259.

8. Ibrahimov A.D. "Production of diaphragms for tyre vulcanization // Industrial production and application of elastomers". Moscow, 2008. № 5-6. P. 22-25. 
9. Aghakishiyeva M.A., Bilalov Y.M., Ibrahimova S.M., Movlayev I.G. // "Vulcanizited rubber mixture" Az.R Patent I 2009 0137, 20.07.2009.

10. Bilalov Y.M., Movlayev I.G., Ibrahimova S.M. "Modification of rubber mixture on the basis of isoprene and butadiene-styrene rubbers by chlorine atactic polypropylene. Industrial production and use of elastomers. Moscow, 2010. № 1, P. 23-24.

11. Bilalov Y.M., Movlayev E.G., Ibrahimova S.M., Mustafayeva R.E. "Obtaining and study of tyre rubbers on the basis of modified butadiene-styrene rubber. Industrial manufacturing and use of elastomers. Moscow, 2011, -№3, -P.30-34.

12. Bilalov Y.M., Ibrahimova S.M., Mustafayeva R.E., Movlayev I.M. // "Vulcanized rubber mixture" Az.R patent I 20140070, 04.11.2014.

13. Guide for rubber worker V.I. // Rubber and ingredients. MAI, 2012. P. 518-525.

14. Technological regalement. BTP № $326-85$.

15. Movlayev I.H., Ibrahimova S.M., Amirov F.A., Mammadova G.M., Guliyeva A.Y. "Use of filler in side rubber mixture of the waste formed during the development of dolomite fields”. Ecoenergeties. № 2, 2013. P. 43-46.

1. Movlayev I.G., Ibrahimova S.M., Zeynalov N.A., Mamedova G.M. // "Use of waste formed in decomposition of dolomite field as a filler in rubber mixture". Azerbaijan journal of chemistry. № 2, 2015. P. 77-80.

16. Movlayev I.H., Gurbanova Z.R., Gaziyeva G.R., Asgerov H.F. "Use of aluminium fluoride production waste in the mixture of auto inner tube. Ecoenergetics. № 3, 2012. P. 33-37.

17. Movlayev I.G., Ibrahimova S.M., Amirov M.A. // "Use of waste of raw material processing as activator of rubber mixtures vulcanization”. Industrial manufacture and use of elastomers. № 3, 2013. P. 15-19.

18. Pozin M.E. "Technology of mineral fertilizers" L:, Chemistry, 1982. P. 352.

19. Adilova M.R. "Influence of magnesium compound on the content and physico-mechanical properties of ammonized double superphosphate. Uzbek chemical journal, 1983. № 1. P. 52-57.

20. Mamedova G.M., Ibrahimova S.M., Mamedova L.R., Atayev A.Sh. "Use of waste formed in the development of dolomite field as lime fertilizer”// News of higher educational organizations of Azerbaijan, 2015. № 5. P. 28-31.

21. Pozin M.S. "Technology of mineral salts" // L. Chemistry, 1974. P. 1556.

22. Az.R Patent I 20020140, 14.04.2009 - "Method of obtaining of aluminum fluoride".

23. Alosmanov M.C., Ibrahimova S.M. "Research of obtaining process of aluminum, decomposition of hydroxide aluminum and red slime of silicium fluorhydric acid”. Chemistry and Petrochemistry, 2005. № 1. P. 60-68.

24. Alosmanov M.S., Ibrahimova S.M. "Mechanism and kinetics of the process of aluminium fluoride obtaining by decomposition of aluminium containing mixture of silicium fluorhydric acid". Chemistry and petrochemsitry, 2002. № 1. P. 89-92.

25. Gazvini K.A., Atayev M.Sh., Ibrahimova S.M., Alosmanov M.S. // "Study of the process of making harmless auto industry waste waters Ecoenergetics, 2013. № 2. P. 31-33. 